\title{
The Role Of Regional Planning In Achieving Economic Develop- ment And Social Justice In Sudan
}

\author{
https://doi.org/10.21272/sec.4(2).101-113.2018
}

\section{Mohamed Abdalla Mohamed Ahmed}

Dr., Associate Professor of Economics, at Department of Economics, Faculty of Economic and Administrative Sciences, University of El Imam El Mahdi, Sudan

\begin{abstract}
The aim of the paper is to define the importance of regional planning and regional development projects and their role in achieving economic development and social justice in the Sudan, by knowing the impact of regional planning on achieving the principle of balanced development between the center and regions. As well as the impact of regional development projects and their role in achieving political, economic and social stability of urban and rural communities.

The paper assumed that Sudan's development plans and programs did not take into account the issues and needs of the community for economic development and social justice.

The citizens of regions and states are not actively involved in the development of regional and local development programs and projects.

The paper used the historical and descriptive analytical method to extrapolate reality. The paper relied on secondary data sources such as reference books, some studies and official reports, statistics and data on regional development projects.

The paper concluded with the most important results that the planning of development in Sudan does not occur at the level of the states and regions, and the consequent creation of many of the political and social problems that put the country away from the path of development and progress.

And that there is a lack of specialized structures concerned with the process of development planning at the local and regional levels, which in turn reflects negatively on the effectiveness of the process of regional development planning.
\end{abstract}

Keywords: regional planning, regional development, economic planning, economic development, social development, social justice.

JEL Classification: B00.

Cite as: Mohamed Abdalla Mohamed Ahmed (2018). The Role Of Regional Planning In Achieving Economic Development And Social Justice In Sudan. SocioEconomic Challenges, 4(2), 101-113.

https://doi.org/10.21272/sec.4(2).101-113.2018.

(C) The Author, 2018. This article is published with open access at Sumy State University.

\section{Introduction}

The issue of economic development came in the wake of the Second World War and the division of the modern world into two worlds, one rich and the other backward. These circumstances led to the issue of economic development as one of the main issues that drew the attention and attention of the international community considering that development is the human issue itself and its goal.

Therefore, many States have decided to plan their resources to achieve the goal of development. They have taken the economic planning approach as a practical science and practice to channel their material and human resources to economic and social development. As the planning process seeks to change reality, Society and the economic, social and political realities in it, which in turn contributed to the development of regional planning which deals with the study of the environment and natural and human resources, whether exploited or untapped in a specific area of land. The potential of the Territory and its available resources to be exploited and exploited for economic development. The establishment of national planning on the basis of regional planning emphasizes that development programs and projects reflect the real potentials and needs of each region, 
and this will achieve balanced development between regions and within each region within the framework of specialization and regional integration within the same country .

\section{Paper Objective}

The aim of the paper is to define the importance of regional planning and regional development projects in Sudan and their role in achieving economic development and social justice by:

1) Knowing the impact of regional planning on achieving the principle of balanced development between the center and the regions.

2) To know the impact of regional development projects and their role in achieving political, economic and social stability of urban and rural communities.

\section{Paper Problem}

The view of the nature of the Sudanese economy finds a difference in the level of economic and social development between the different states of the country, as a result of the development policies adopted since the colonial era, which was the focus of development efforts throughout those years in the Nile region, where concentrated most of the private agricultural projects and government, In addition to industries and education and health services compared to other regions of the country, and the concentration of development and services in this way has created a development gap in the areas of the traditional sector.

\section{Paper Hypotheses}

1) That the development plans and programs in the Sudan did not take into account the issues and needs of the community to bring about economic development and social justice.

2) Citizens of regions and states have no active participation in the development of regional and local development programs and projects.

\section{Paper Methodology}

The paper adopted the historical and descriptive approach to extrapolating the reality. The paper also relied on secondary data sources such as reference books, some studies and official reports, statistics and data on regional development projects.

The paper recommended the need to consolidate the regional dimension in all policies, plans and programs at all national, regional and local levels in order to achieve balanced regional and urban development.

In-depth scientific studies should be carried out for all the states of the Sudan to inventory the state's resources, so that development plans and programs can be developed that reflect the true potentials and needs of all the regions of Sudan, in order to avoid the disadvantages of previous development plans and programs.

\section{Paper Structure}

The paper deals with four axes, the first focuses on the conceptual framework of the issue of economic development, regional planning, the second axis, regional planning theories and the experiences of the world countries in this field. The third axis deals with Sudan's experience in the field of development planning, decentralization and its relation to economic development, and the fourth axis, and last axis is exposed to the reality of regional development. Imbalance in Sudan and its relationship to social justice.

\section{Axis I: The issue of economic development}

The issue of economic development took the lead in the world after World War II, as the most important and difficult problem faced by countries suffering from economic underdevelopment. Many of these countries considered that they plan to use their resources to achieve the goal of development. To achieve economic and social development goals.(Sayed Nimeiri, Economic Planning in Sudan, 1978, p. 5).

\section{The concept of economic development}

It is not easy to provide a clear definition of economic development because of the different economic, social and political conditions prevailing in all countries and the stages of economic progress. However, the most accurate and acceptable definition of economic development is the definition of d. Abdul Aziz Mukhtar as "all planned operations and efforts that are aimed at creating a series of successive social and economic changes 
intended to increase the welfare of the members of society and move society from a certain social and economic situation to a better situation (Abdul Aziz Abdullah Mukhtar, Planning for the development, 1995, p. 31).

Thus, through the definition of economic development, it is closely linked to the process of economic planning as one of the means capable of achieving development.

\section{Economic Development Planning}

Planning for economic development is a necessity that is no longer indispensable for the advancement of the life of societies in our time. Through it, it is possible to address the problems of underdevelopment and achieve rapid rates of development in the shortest time possible, at the lowest possible cost and with minimal waste of material and human resources.

Economic development planning is a type of comprehensive planning or national planning, where development efforts in this area, ie, economic development planning, began after the Second World War. The Marshall Plan, which aimed to restore the economic and social life of Western European countries after World War II, The second was the first major effort in the field of planning for economic development. The United Nations sponsored these development efforts in all countries of the world. The first decade of development was in the 1960s and the second decade in the 1970s.(Mohammed Bakri, Manpower Planning Seminar,1980, p. 30).

The experience of the previous two decades has shown that planning for economic development did not reach developing countries the goals they sought, because they focused on national output and per capita income in economic growth, and largely neglected the social and cultural development of countries. Despite the increase in overall growth, The economic situation of the majority of developing countries has not improved much, exacerbating the problems of unemployment and increasing rates, increasing migrations from rural areas to cities and declining educational and health services. The voices are calling for a new model of development that reduces the specter of unemployment and increases the redistribution of income National focus on physical capital and rely more on human capital as a key factor in the production and accumulation of capital and the purpose and goal, which is heading towards it economic, social and cultural efforts and reduce.

As a result, development efforts have increased in all countries of the world, although their models differed. However, the General Agreement emphasized the importance of planning these efforts,

\section{What is economic planning?}

Increasing attention to planning as a scientific and practical means of directing the resources of the society (material and human) to achieve the goals of economic development and social justice, planning is relatively new method, due to the experience of socialist countries at the beginning of the last century. Today is a basic system for directing the economy in most developing countries.

\section{National planning and regional planning}

National planning means that the economic plan includes all the administrative regions of the state, "provinces," and national planning means that the distribution of economic plans the total investment that is expected to achieve during the years of the plan twice on different branches of economic activity and once on the administrative areas of the state.(Ali Lutfi, Planning Theory and Application, 1988, p. 33).

Regional planning is intended to prepare and implement an economic plan for a particular administrative area, "Wilayat, Mohafazah, Mohsen" and regional planning, as a result of the geographical imbalance of economic growth following World War II in Western countries.

Regional planning may be part of national planning, in which case regional planning is a decentralized form of planning at the geographical level.

Regional decentralization in the development, implementation and follow-up of the national plan.

In conclusion, the principle of economic planning should be national, ie, inclusive of all administrative regions of the country, in order to guarantee the geographical balance of economic growth, but this does not preclude the existence of a regional plan within the framework of the national plan. In pushing the economic development process forward.

\section{Regional Planning Concept}


Regional planning means the preparation and implementation of an economic plan for a particular administrative area within the state, "state, province, province" because of its relative backwardness or because of its great importance in advancing the process of economic development.

Several schools of thought have emerged to define regional planning rooted in the philosophical differences of the concept of regional planning depending on the definition of temporal and spatial forms and hence its objectives.

Known by d. (Samir al-Radaisi) as an attempt to lead regional development and includes a number of overlapping economic, political and social processes that occur within the spatial framework known as the territory.(Samir Mohamed Ali Al-Rudeisi, (1998) Introduction to Regional Planning, p. 18).

Dr. Abdel Aziz Mokhtar defines it as a deliberate and systematic attempt to study regional problems and within the overall structures of society or the state and solve these problems for the purpose of developing the region.(Aziz Abdullah Mukhtar, (1995) Planning for the development, op.cit., p. 135).

\section{Motivation for Regional Planning}

By defining the concept of regional planning and its forms, it is clear that the reasons for its adoption are primarily due to the difference in the type and size of the resources available in the regions of the same country which lead to different rates of economic growth. Consequently, regions with abundant resources, Both have higher rates of development and become richer economically than other regions with less resources. This development leads to imbalance and homogeneity in development rates at the national economy level.

In addition, the rich regions become a magnet for the population in the poor regions, and as the population continues to migrate there is a population explosion that adversely affects the development efforts of the rich regions, as well as the social problems associated with it, "displacement". Justified in terms of ensuring the balanced growth of all regions and achieving the economic and social well-being of the entire population.

\section{Regional Planning Objectives}

The ultimate goal of any planning is to achieve economic growth and to raise the standard of living. This necessarily necessitates the fullest utilization of all available resources in society, hence the importance of introducing new regions into economic activity.

Regional planning aims to achieve a degree of balance in the growth of the regions of the country, and this necessarily follows the study of the potential of each region and the allocation of the most appropriate investments. The adoption of the national economy on the regional development planning will provide better conditions for development, considering that regional development planning achieves the following objectives (Mohamed Ghanem, Environmental Integration of Development, p. 8).

1. Regional planning helps to combat poverty and unemployment and reduces migration to cities.

2. Regional planning seeks to reconcile economic and social development with the preservation of the local environment.

3. Reduces economic and social disparities within a framework of regional integration among the regions of a single State.

4. Political, economic and social stability of urban and rural communities.

5. Seeks to avoid regional imbalance of economic development and achieve social justice.

\section{The second axis: The theories of regional planning}

The theory in regional planning is a philosophical concept that aims at framing ways to formulate and implement regional growth. The theory is linked to regional philosophies and capitalist and socialist ideologies. Therefore, the development of theories in regional planning can not be limited to one type of human thought.

The theory of stages of growth

This theory attempts to regulate the process of economic growth through sequential stages and apply them to the national and cultural borders of states, and the pioneers of this theory, Marx and not Fischer and others. In his theoretical assumptions, Marx defined stages of growth in primitive communist order, ancient slavery, central feudalism, and industrial capitalism. The main step in agricultural development was the exclusion of traditional agriculture in order to effect structural changes. 
In the Marxist system, the economic aspects evolve through these stages, driven by the forces of conflict between two strata, one controlled by the means of production associated with labor, the other does not have the means of production but it possesses the labor, and the class struggle reflects the constant contradiction between the development of economic institutions and advances in production technology.

On the other hand, "List 1885" has developed its classification of stages of economic growth on "shifts" in functional distribution. The stages of growth suggested by the "List" consist of the savage phase, the pastoral stage, the agricultural phase, And commercial agricultural processing.

Fisher sees the regular shift of work and investment from primary to secondary activities and then to the tripartite activities that accompany economic progress.

The similarity between the stages of growth assumed by List and the concept of primary, secondary and tertiary production of Fisher is an important element of regional planning theory. In general, the Fischer model had a clear impact on national and regional economic policies after World War II, Manufacturing

\section{The theory of the growth centers of Peru (1950): Per roux}

This theory suggests that growth stems from certain geographic regions or points that enjoy some advantages such as geographical location or some economic resources. Such development centers are a pioneer in the field of economic growth in general and industrial growth in particular, and are in the early stages of development superior to other regions of the country Over time, however, the disparities gradually and automatically disappear after the regions of the leading regions have become infected.

According to Friedman (1966), it is necessary to change the nature of the spatial relations between the advanced development centers and the backward margin areas, so that these advanced development centers will export the development to the margin areas by strengthening the economic and social relations between them.

The theory of growth centers is based on the integration of three basic elements: industrial location, industrialization and regional development. It is therefore necessary for development plans at the national and regional levels to create a new framework for adopting a more conscious industrialization policy for regional and social analysis.

\section{Center Theory - Margin}

This theory is linked to Friedman's 1966 ideas, in which he focused on the spatial transformations of economic growth, relying on Rusto's conception that regional policy is critical policy in transitional societies moving from the agricultural economy to the industrial economy.

The theory of the center of margin is based on the concept of bilateralism in society, in the presence of two different sectors in terms of economic production patterns and cultural and civilizational background, namely the traditional sector which depends on the traditional means of production, and the modern sector, which is a leading center in the process of spreading development by creating links (Linkages Between the subordinate and the subordinate sector, and on this basis, capital, workers, economic institutions and others are moving towards the center, and the margin situation deteriorates further because of the cyclical trends. "In the long run, when the country moves beyond the industrialization stage and enters the stage of consumption As a result, the imbalance between the regions in one country will decrease and the sovereignty of the center's region will be reduced, thus highlighting the interdependent interdependence of cities.(Rostow 1960 is one of the most important models of spatial growth. The Rostow model consists of four phases, which include the traditional stage of society, the start-up phase, the leadership stage towards maturity, and the stage of moving towards broad consumption.).

The application of the center-periphery theory to include large parts of Africa, Latin America and Asia in the world capitalist economy, which is the center of the world economy, and under this system flows products from colonies to Europe, which helps to provide and move the economic growth of the colonial center .

\section{Regional planning experiences in the world}

The world, particularly the Western European countries of the 20th century, defined models of regional planning, most notably the Greater London planning model. The goal of achieving balanced development and easing the pressure on London was to redeploy about one million people outside the capital, The new cities project. 
The French experience, such as the planning of the region of the Paris Basin (ile-de-France) within the framework of the plan for the formation of French territory, which is based on the theory of poles of balance between the various French regions, the model of regional planning in the Netherlands, within the framework of the comprehensive plan 1966/2000 for all regions of the Netherlands, In the 1976 amendment to the plan. One of the most important elements of the overall plan was the Rand stadium plan, the capital region, and the regional planning of the North East Bulder of the Netherlands, and many consider the Netherlands to have provided a clear model for regional planning.(http://www.algeria-tody.com,fourm/\#_ftnv/2009).

\section{Planning in socialist countries}

It came to eliminate the state of differentiation between the regions, since the goal of regional planning in the socialist countries is the lack of differentiation between the regions, which required that regional plans be consistent with the central plans of the state, in other words, regional plans are developed and implemented centrally, A territory should be in line with the country's top central plan for a certain period, which gives each region a cycle of spatial development.

In this regard, it is not impossible to deny the early stages of regional planning in the socialist countries whose spatial plans sought to follow the same mode of capitalist states as the investment of energies and resources in areas with sufficient resources and resources. In Poland and even Russia after the Second World War, the next stage of the practice of regional planning was to focus on backward areas through the potential of the developed economy created by the first phase. And its well-developed in different regions, and although some of them had not achieve big profits and sometimes losses, but their ability to survive and success in the development of the region socially and economically is considered a profit because it is the desired regional plans.

\section{Planning in developing countries}

We mean developing countries from the point of view of planning those countries which are characterized by significant differences in urbanization between their regions and the abundance of underdeveloped areas, and the emergence of a clear distinction between areas where development and those left without economic projects are those countries with administrative and technical characteristics that vary country by country The extent to which the methods of central planning or how to make a decision, so the regional planning in Iraq, for example, is different in Egypt and different in India or Venezuela or Brazil of different qualities in these countries or all were described as developing,(http://www.algeria-tody.com,fourm/\#_ftnv/2009).

India's regional planning experience, which began in the late 1940s and early 1950s, was the result of severe development problems in large cities and regions as a result of the migration of large numbers of people from the surrounding countryside to city centers, resulting in the waste of many resources in the surrounding cities and associated with them economically and socially. .

In general, it is possible to say that the period of the sixties and the following was the beginning of the work of the regional planning method in developing countries, especially in the seventies after the success achieved by the socialist and capitalist countries alike. The experience of Iraq, Egypt, Brazil and India was a clear evidence of success of the idea of regional planning in developing countries, Methods and levels of achieving their respective objectives.

\section{The third axis: Sudan's experience in the field of development planning}

The first attempts to plan the Sudanese economy began in 1899, with the beginning of the English-Egyptian bilateral government, which introduced a simple and effective administrative system based on a policy based on five guidelines prepared by Lord Cromer:(Abd al-Rahim Marghani, Development Planning in the Sudan, 2002, p. 8).

1. Good management.

2. Population growth.

3. Improved communications.

4. Expansion of water supply and cotton cultivation.

5. Ensuring adequate supply of low-cost fuel.

The five guidelines were the first efforts in the area of development planning by the colonial government. The focus was on good governance to resolve disputes over the land and focus on population increase because their numbers were few as a result of wars and diseases. , By Mr. Wengat Pasha, the Governor-General of Sudan, 
adding a "sixth" point, which is the launching of a simple education system to meet the immediate requirements of the Government of workers, officials and administrators.

These guidelines give the idea of directing most of the investments to projects favored by the colonial rule, namely the construction of railways, bridges, Bosnia, telegraphs and some public facilities. A small part of the investments were directed to irrigation and cropping.

The administration in Sudan was aware of this trend and for the first time since its establishment prepared what can be called development and reconstruction programming, the Committee for Priorities for Reconstruction was formed. The committee's task was to ensure the safety of post-war reconstruction and reconstruction projects and to make recommendations on the priorities of its implementation. The main outlines of the programs of the first five-year reconstruction plan (46-1951) were approved for spending on (193) projects. Most of these projects were not productive; they were a program for spending on some government buildings, electricity, education and health. Uploading of the Sennar Reservoir.(Osman Ibrahim Al-Sayyid, The Sudanese Economy, 2002, p. 359).

The first program of reconstruction was primarily a service program aimed at providing drinking water, electricity, education, and roads. Investment funds were distributed, with the construction and road construction sector accounting for $49 \%$ of investment, agriculture and rural water development $21 \%$, irrigation $19 \%$, education 11\% Total credits (Sayed Nimeiri, Economic Planning in Sudan, op. Cit., p. 27).

At the end of the first five-year plan, it was necessary to arrange for a mechanism to plan and prepare the second five-year plan (51-1956). The Development Committee was appointed by the members of the Executive Council and its members were granted wide powers. In order to protect and improve the standard of living of the population.(Moharir and Kagwe, Administrative Reforms Development Planning in the Sudan (561975) p. 28).

Table 1. Distribution of investments to the economic sectors in the second five-year reconstruction plan 1951-1956

\begin{tabular}{|l|c|c|}
\hline \multicolumn{1}{|c|}{ Sector } & Amount in million pounds & Percentage \\
\hline Transportation & 9.3 & $27 \%$ \\
\hline Production projects & 7.8 & $23 \%$ \\
\hline Services Projects (Education and Health) & 6.9 & $20 \%$ \\
\hline Public utility & 5.1 & $15 \%$ \\
\hline Administration & 4.1 & $12 \%$ \\
\hline Unallocated reserve & 0.8 & $0.3 \%$ \\
\hline Total & 34.00 & $100 \%$ \\
\hline
\end{tabular}

Source: Moharir and Kagwe, p. 28.

Although the first and second development programs did not achieve the desired results in improving living standards, they led to some expansion in education, health and public services.

After that, the first national government started the first attempt to develop a five-year plan covering the years (57/1962) but did not come into being. The cost of projects submitted by ministries and government departments exceeded all the resources available locally and abroad. (57/1958) and the other year (58/1959) and so continued to develop plans and budgets annual as it was not possible to develop a five-year plan until the change of government in November 1958, came a new government has strengthened the importance of national planning and launched ambitious programs for economic and social development, The Birth of the Ten-Year Plan for Economic Development (1961). (Moharir and Kagwe, op.cit, p.28).

Which was the first real experiment of national planning after independence, a period in which planning has achieved a kind of planning maturity and addressed many of the weaknesses and shortcomings that have been impeded previous planning attempts in the country.

Therefore, given the previous planning attempts in the Sudan in the period from (46/1960), it is very clear to us that it is difficult to consider the development of plans, whether five or annually, because they lack the basic elements of the plans, whether in terms of objectives or scientific preparation correct or the absence of the central body Specialized and experienced in the preparation of plans and coordination between different projects or in terms of involving the private sector in the development and implementation of these plans. 


\section{Economic development in Sudan}

The composition of the Sudanese economy from the beginning of the British colonial era to the end of the bilateral rule reflected a difference in the level of economic and social development between the different regions of the country, because the colonial government was focusing development efforts throughout the years of rule in the Nile region north and south of Khartoum, Private and government sectors, as well as industries, education and health services compared to other regions of the country. This disparity was reflected in the economic development between the different regions and directorates of Sudan, and within each Directorate at the same time.(Tim Tabluk, Conflict of Power and Wealth in Sudan, 1994, p. 138).

Table 2. Regional distribution of investments in the year 1955/1956 (thousands of pounds)

\begin{tabular}{|l|c|c|c|c|c|c|c|c|}
\hline \multicolumn{1}{|c|}{ Regions } & $\begin{array}{c}\text { Total } \\
\text { investme } \\
\text { nt }\end{array}$ & $\begin{array}{c}\text { Percent- } \\
\text { age }\end{array}$ & $\begin{array}{c}\text { Governmental } \\
\text { investment }\end{array}$ & $\begin{array}{c}\text { Percenta } \\
\text { ge }\end{array}$ & $\begin{array}{c}\text { Public } \\
\text { institutio } \\
\text { ns }\end{array}$ & $\begin{array}{c}\text { Percenta } \\
\text { ge }\end{array}$ & $\begin{array}{c}\text { Private } \\
\text { investment }\end{array}$ & $\begin{array}{c}\text { Percenta } \\
\text { ge }\end{array}$ \\
\hline $\begin{array}{l}\text { Khartoum, North, } \\
\text { Kassala }\end{array}$ & 11906 & $56 \%$ & 4770 & $64 \%$ & 1276 & $32 \%$ & 5860 & $60 \%$ \\
\hline Blue Nile & 4178 & $20 \%$ & 1147 & $15 \%$ & 721 & $18 \%$ & 2310 & $23 \%$ \\
\hline Kordofan and Darfur & 3533 & $17 \%$ & 1035 & $14 \%$ & 1325 & $34 \%$ & 1173 & $12 \%$ \\
\hline Southern provinces & 1716 & $7 \%$ & 514 & $7 \%$ & 610 & $16 \%$ & 492 & $5 \%$ \\
\hline All Sudan & 21233 & $100 \%$ & 7466 & $100 \%$ & 3932 & $100 \%$ & 9835 & $100 \%$ \\
\hline
\end{tabular}

Source: Tim Tablock, p. 138, citing national income statistics in 1955/1956.

From the above table we note that the share of Khartoum, North and Kassala administrations from the total government and private investments was eight times the share of the southern directorates and three times the share of the administrations of Kordofan and Darfur.

Despite this large disparity in the distribution of investments between Sudan's different regions, there is a disparity in the standard of living and per capita income shown in Table 3 below:

Table 3. Regional Distribution of GDP in 1955/1956

\begin{tabular}{|c|c|c|c|}
\hline Regions & $\begin{array}{c}\text { Gross Domestic Product } \\
\text { (Thousand Pounds) }\end{array}$ & $\begin{array}{c}\text { Population in } \\
\text { thousands }\end{array}$ & Per capita income in pounds \\
\hline Khartoum, North, Kassala & 75788 & 2319 & 33 \\
\hline Blue Nile & 86038 & 2070 & 42 \\
\hline Kordofan and Darfur & 83777 & 3091 & 27 \\
\hline Southern provinces & 38610 & 2783 & 14 \\
\hline
\end{tabular}

Source: Tim Tablock, p. 140, citing national income statistics in 1955/1956.

We note from the previous table that per capita income in the Blue Nile Directorate is three times the per capita income of the southern districts. If we take into consideration the size of the population, the disparity in the standard of living will make the distribution of income clearer.

After the independence of the Sudan in 1956, national governments inherited a central pattern in the planning, economic, social, political and administrative development that was concentrated in Central Sudan. This central pattern served the colonizer's objectives of optimizing Sudan's resources and the lowest cost for its industrial growth in Europe, especially Lancashire And the British fabric, which was adopted mainly in its renaissance on the cotton of the island project. And focusing geographically development projects in central Sudan in what is known as the Triangle of Prosperity (Khartoum, Kosti Sennar). The phenomenon of center and margin began with the gradual widening of the gap in the following areas:(Jomaa Kende Koumi (2008) Paper at the symposium on peace and the future of unity in Sudan, held at the University of Juba, on the status of the three regions and their impact on Sudan's political future, Al-Sahafa newspaper No. 45297 dated 18/3/2008).

A) Economic, agricultural and industrial development: For example, in the field of industrial development and investment, until 1980 the prosperity triangle had more than $75 \%$ of the total factories in Sudan.

B) Development of participation in the leadership of administrative and political work. Astudy conducted in 1981 indicates that 84\% of the highest grades in the civil service in Sudan are occupied by the Center and 16\% only by the rest of the Sudan. 
This variation in development between the center and the regions has had negative effects on the regions. The most important of these effects is the disruption of the social and economic structure in these areas due to several phenomena,

(A) Selected migration from the people of the Territories to the Center and their becoming part of the mechanisms governing the Center over the Territories.

\section{Decentralization and Economic Development in Sudan}

That decentralized opinions and arguments are diverse, starting with the contribution of decentralized governance to the political development process by training leaders through the exercise of political action in local government, and ending with the material benefits of local investment in economic and social projects. Local or regional government authorities can play a key role in achieving the main objective of developing countries to secure the greatest return from available human and material resources and to raise the standards of living in those countries.

Most countries in the world now tend to assume greater responsibilities in the areas of economic, social and political development, not only in the past providing primary services, but also in the area of planning and implementing projects development.(Shaykh alDin min Allah, (1998), Local Government during the Century (1899-1998) p. 40).

Decentralization in the area of regional planning and development is aimed at adapting development programs to the needs and requirements of the community, as it allows communities to participate in the process of preparing and implementing regional development plans in their regions, and provides necessary support for mobilizing energies and mobilizing resources. National development in achieving its objectives in a balanced manner.

The Government of the Sudan has been alerted to this situation and has begun to take a series of measures that would achieve balanced regional development or at least alleviate the economic and social disparities among the regions of the one State. The most important measures taken during the May- The Center is dedicated to the regions and to the policy of opening up to the countryside to serve the purposes of regional development. Regional development is not only achieved from the bottom up, but through the active participation of development-oriented communities, Mind that the process Development in general and regional development in particular are complex and complex, and are not easy to plan, implement and follow-up from the center.

In 1980, the same government set up economic planning units in the regions. A budget was created for each unit. A department called the Regional Development Department was established to identify the regional development projects in the regions. It was funded by the Ministry of Economic Planning. This situation continued until 1984, Followed by the coup d'état (May government), in which the development process was almost halted, with the focus on political action and the absence of development projects.(Tajani Assum Point, (2007), Evaluation of Regional Development Project Planning Processes, unpublished PhD thesis, University of Sudan, Faculty of Economics, p. 81).

When the National Salvation Government came in 1989, Sudan was divided into states instead of provinces. The powers of the administrative center were transferred to the states as a means of promoting economic development. The involvement of the states in the planning and implementation of regional and local development projects would strengthen the sense of citizenship. In the process of economic and social development, the State Development Department was established by the Ministry of Economic Planning and eventually transferred to the State Support Fund.

Thus, through our review of the development plans and programs in the previous and subsequent periods of the period of the independence of the Sudan until the last program, most of them focused on sectoral development and did not care about planning for regional development through the equitable distribution of investments to the different regions of Sudan, which led to the deterioration of development in some And the consequent emergence of political movements in those regions and regions called for the elimination of marginalization and development in their regions.

Therefore, this situation leads to the need to attract the process of regional planning for development in Sudan in the future in order to avoid the disadvantages and failures of those plans and programs and to achieve sustainable regional development for all regions of the Sudan. 
(B) Exploitation of natural resources of the natural regions at the lowest cost for the center where they are manufactured, raised and returned at high prices as consumers in the same regions.

(C)Exploiting the resources of the unskilled and unskilled regions in marginal and service work for the wellbeing of the Center's society and economy.

These phenomena led to the collapse of development pillars, not only in the regions, but also in the center of its dependence on the natural and human capabilities of the countryside in its development. Consequently, national development gradually collapsed, resulting in political turmoil and economic and social crises in Sudan. From less developed areas to more developed areas. This disparity and imbalance in economic development have had significant political effects and consequences. These influences differ from region to region depending on the interaction of political, social and historical factors. In the southern regions, for example, the call for self-rule and separation emerged as a result of cultural, historical and economic differentiation. In other regions, regional movements took other forms, focusing on protesting the development neglect of the state and demanding their economic, social and cultural development.(Tim Nabluk, op. Cit., p. 140).

\section{Axis IV: Planning for Regional Development in Sudan}

Regional development is a more comprehensive concept that takes an economic and social dimension. It means benefiting from the relative and absolute resources and advantages enjoyed by a particular region so that it is an integrated economic unit with common geographical and natural advantages and factors.

The planning of regional development is one of the most important means to eliminate the phenomenon of regional and spatial disparities in the levels of economic and social development, in order to achieve national development goals.

The talk of planning for regional development in Sudan was first mentioned in the Sixth Plan of Economic and Social Development (1977-1983), where a full section of the plan was called regional development. The attention paid to regional planning by the state in that period showed the reality of regional development Which has been subject to scientific studies and research by Sudanese and foreigners.(The Sixth Plan for Economic and Social Development (77 / 78-82 / 1983) Volume I, 1976, p. 46).

In 1971, the Government of the Sudan requested a mission from the ILO to assist in the analysis of the Sudanese economy and to present its proposals on what the Government of Sudan should do to achieve three purposes of concern to the international community: growth, employment and equitable distribution of wealth.

In 1976, the Mission submitted its report to the Government of the Sudan in conjunction with the beginning of the six-year plan (77-1983), which the Government was preparing, in the hope that the plan would take into account the results of the study: (Adam Al-Zein et al. (2003), p. 7-8).

First: Sudan's economy as a whole is an agricultural but dualistic one. The modern agricultural sector is dominated by mechanized irrigated and mechanized agriculture, and the traditional agricultural sector is based on livestock breeding and rain-fed agriculture without using the machine.

Secondly: the traditional sector is mainly in the southern region and western regions (Kordofan and Darfur) and some areas in the rest of Sudan.

Third: Economic development projects and service projects (health, education, etc.) over the years concentrated in the areas of the modern agricultural sector.

Fourthly: the focus of development and services in this way has created a development gap in the areas of the traditional sector.

Fifth: About $75 \%$ of productive employment comes from the traditional sector.

Sixth: production inputs in the traditional sector are less expensive than in the modern sector. However, the return on investment in both sectors is almost equal.

The mission concluded with its main recommendation that the six-state plan, which the state intended to produce, should give the traditional sector the largest share of investment.

In 1979, Martin Adams and John Howell published an article in the journal Economic Development Cultural Change (The Development of the Traditional Sector in Sudan) and concluded that the Sixth Plan (77/1983) did not follow the ILO recommendation but continued to focus on development And services in the modern agricultural sector, while giving the traditional sector little development projects here and there. 
The International Labor Organization (ILO) was not the only one to draw the attention of the Government of Sudan to the phenomenon of uneven development and its relationship to developmental injustice. In 1974, David Rodin published an article entitled "Regional Developmental Disparity and the Sudan Rebellion" in The Geographical Review (vol. The fourth issue of October 1974 was linked to the rebellion in southern Sudan and the relative developmental underdevelopment of that region. Moreover, Rodin proved the fact of the development focus in the center of Sudan, which dates back to the era of foreign rule, which was biased to the theory of development. Pole Theory) (Adam al-Zein et al., Op. Cit., p. 9).

In 1977, Less and Brooks published an English book entitled Economic Development and Politics in Sudan, discussing the uneven development of Sudan. One of the criticisms of development policies in Sudan was the unfair and equitable distribution of efforts (Khartoum and Al-Jazira) and stressed that an important aspect of the progress of the development process in Sudan in the future is that the tendency towards geographical areas (regions) to achieve integrated rural development will prevail (Less and Brooks, Economic and Political Development, p.141, 1977).

As well as recent studies carried out by the university professors of Sudan and published by the Center for Peace Studies at the University of Juba in 2003, a seminar (development key to peace in Darfur), which proved the regional disparity in development for all regions of Sudan and this contrast is evident in comparison, as some Sudan's regions are less fortunate in development than others, pointing out the need to remove the relative disparity between the regions in the field of development in order to avoid the phenomenon of developmental injustice and its damage to national unity.

The uneven distribution of investments is a cause of large regional disparities between regions in the Sudan and is closely linked to the issue of regional development. Regional development must therefore be seen as an effective way of achieving social justice and an entry point for the redistribution of income and wealth.

\section{Regional Development and the Cause of Social Justice}

The issue of social justice and poverty has been and continues to be the subject of constant concern by many economists and politicians because of their economic, social, humanitarian and political distance, and Sudan's modern political and economic history shows us that the issue of social justice in the Sudan has developed differently in different regions and regions within the state.

This is due to the imbalances between the economic and interregional sectors in the country, which must be addressed within the framework of a comprehensive national vision for development, which sets development policies according to the current economic conditions and the human and material resources available in each sector or region. Unbalanced regional development by working on (Abdel Hamid Brahimi (1997), Social Justice and Development in the Islamic Economy, p. 192).

\section{Reduce imbalances between sectors:}

In terms of sectors of economic activity, the balance between investments in the economic sectors and social sectors should be balanced in order to guarantee the basic social needs while ensuring the sustainability of economic growth.

\section{Reduce regional disparities:}

At the regional level, measures should be taken to reduce disparities while ensuring regional regional balance by redistributing economic activities and income that cause inequitable distribution of imbalances within the state. The concentration of economic activities in urban areas in addition to rapid urbanization has caused regional regional differences.

\section{Decentralization:}

The accelerated implementation of administrative and functional decentralization would encourage local development, because decentralization can play a positive role in combating imbalances at regional and sectoral level.

On a regional scale, least developed regions and regions should be granted independent governance to take on local development and be able to design and implement production programs that can cover basic local needs. 
At the sectoral level, decentralization is the liberalization of creative initiatives aimed at increasing productive investments in the context of economic policy of reducing imbalances between sectors, reducing regional differences and based on the basis of harmony between sectors within the state.

Based on the foregoing, the most promising prospect of overcoming the unbalanced regional development crisis and achieving social justice and social peace in the Sudan is the recognition by the state that some of Sudan's regions are less likely to grow than other regions, Other regions of Sudan have also expressed developmental neglect, such as Darfur and eastern Sudan. This does not mean that other regions in Sudan are happy with their share of development spending.

We conclude from this that the development plans and programs in Sudan are mostly focused on sectoral development and did not concern planning for regional development through the equitable distribution of investments to the various regions of Sudan, which led to the deterioration of development in some regions of Sudan and the consequent emergence of movements The rebellion in these regions and regions is called for development in their regions. Therefore, this situation leads to the necessity of attracting the regional planning process for development in Sudan in the future in order to avoid the disadvantages and failures of these plans and programs,to achieve sustainable regional development for all regions of the Sudan.

The paper reached important conclusions and recommendations that can be summarized in the following points.

\section{Results}

> The developmental policies of colonialism and post-independence have encouraged urbanization and industrialization and have helped to create jobs and services (education and health) in urban areas, which may cause regional and regional differences within the state.

$>$ Planning for development in Sudan is at the level of the sector, not the region, which made some states and regions lack economic and social development and the consequent creation of many of the political and social problems that put the country away from the path of development and progress.

$>$ The economic development projects and service projects (health, education and water) over the years have been concentrated in the modern agricultural sector, and the concentration of development and services in this manner has created a development gap in the areas of the traditional sector.

$>$ There is a lack of institutional and specialized structures concerned with the process of development planning at the local and regional level, and thus the absence of community participation in the planning and implementation of development programs and projects. This in turn, negatively affects the effectiveness of the regional development planning process.

$>$ Development plans and programs in Sudan are moving from top to bottom, do not take into account the needs and issues of development-targeted communities and effectively involve them in the implementation of programs and projects that concern regional or local development.

\section{Recommendations}

$>$ The development planning in the Sudan is in the form of economic sectors and is not based on geographical units (regions). Therefore, regional development planning is the most appropriate framework for economic development and social justice in different states and regions of Sudan.

$>$ To establish the regional dimension in all sectoral strategies, policies, plans and programs at all national, regional and local levels in order to achieve balanced regional and urban development.

$>$ In-depth scientific studies should be carried out for all the states and regions of the Sudan, which should limit the resources of the state or the region and its natural and social conditions so that development plans and programs that reflect the true potentials and needs of all the states and regions of the Sudan can be developed to avoid the disadvantages and failures of previous development plans and programs.

$>$ The development of state and regional councils specialized in development planning in the states, preparing and implementing development programs and projects in different regions of the states and granting them the powers and tasks that enable them to carry out their development tasks successfully, especially in the financial and legislative aspects.

$>$ The local community and the citizens of the states and regions must be involved in the implementation of the projects in their areas and the plans and programs that involve local or regional development should not be taken down from the top without regard to the needs and issues of the population of the area to be developed. 


\section{References}

1. Abdul Aziz Abdullah Mukhtar (1995). Planning for the development of society, Dar Knowledge University.

2. Abdul Hamid Brahimi (1997). Social Justice and Development in the Islamic Economy. First Edition, Center for Arab Unity Studies.

3. Abd al-Rahim Marghani (2002). Development Planning in the Sudan in the 1960s, Awad Hassan Mohammed, Publisher Abdul Karim Marghani Omdurman Center.

4. Adam Zein et al. (2003). Development Paper Key to Peace in Darfur. Center for Peace Studies, University of Juba.

5. Albert Waterston (1982). Development Planning Lessons of Experience. London.

6. Ali Lutfi (1988). Planning Theory and Application. University House, Beirut.

7. Juma Kende Koumi (2008). Paper at the symposium on peace and the future of unity in Sudan, held at the University of Juba, Khartoum, on the status of the three regions and their impact on Sudan's political future, Al-Sahafa newspaper No. 45297 dated 18/3/2008.

8. Less and Brooks (1977). The Economic and Political Development of the Sudan, Manillan Press, London.

9. Mohammed Khamis Al-Zouka (1999). Regional Planning and Geographical Disposal. Dar Al-Maarifa University.

10. Mohamed Sultan Abu Ali (1985). Economic Planning and Methods. Nahdat Al-Shorouk Library, Cairo.

11. Mohammed Ghanem (2004). Integrating the Environmental Dimension of Development Planning. Applied Research Institute.

12. Mohamed Abdalla Mohamed Ahmed (2010). The role of regional planning in the economic and social development in Sudan, the period from 1980 to 2009. PhD in Economics, University of Sudan.

13. Mohammed Bakri (1980). Manpower Planning Seminar. Institute of Management, Riyadh.

14. Osman Ibrahim Al-Sayyid (2002). The Sudanese Economy. Dar Al-Quran University. Second Edition, p. 359.

15. Sayed Nimeiri (1978). Economic Planning in Sudan. University of Khartoum.

16. Samir Mohammed Ali Al-Rudeisi (1998). Introduction to Regional Planning. First Edition, The Foundation of Education for Printing and Publishing.

17. Sheikh Aldin min allah (1998). Local government during the century presentation of the experience of Sudan (1899-1998). Sudan printing press, Khartoum.

18. Sixth Plan for Economic and Social Development (77 / 78-82 / 1983), Volume I, Ministry of Finance and Economy, Khartoum, December 1976.

19. Tijani Assum (2007). Point, Evaluation of the Planning, Implementation and Follow-up of Regional Development Projects in Sudan, Case Study of Southern Kordofan State from 1995-2005. PhD in Public Administration, unpublished, University of Sudan.

20. Tim Tabluk (1994). Conflict of power and wealth in Sudan. Translation of Al-Fateh Tijani, Khartoum Publishing House, second edition.

Web sites:

1. http: //www.algeria-tody.com. 